\title{
The Isolation of $\alpha$-viniferin,
}

\section{A Trimer Stilbene, from Shorea ovalis Blume}

\author{
Noviany \\ Department of Chemistry, University of Lampung, Bandar Lampung 35145, Indonesia \\ E-mail:nv_any@yahoo.com \\ Sutopo Hadi (Corresponding author) \\ Department of Chemistry, University of Lampung, Bandar Lampung 35145, Indonesia \\ Tel: 62-813-69059733Ｅ-mail: sutopohadi@unila.ac.id
}

\begin{abstract}
The derivative of oligomeric stilbene compound which was identified as $\alpha$-viniferin, a trimer stilbene, was successfully isolated from acetone extract of stem bark of Shorea ovalis Blume (Dipterocarpaceae). The isolation of this trimer stilbene from this Shorea plant has never been done previously. The purification methods included extraction, partition, and fractionation with vacuum liquid chromatography and then followed by gravity column chromatography. The structure of the compound isolated was determined based on the analyses of physical data, UV and IR spectroscopies and compared to the standard compound of $\alpha$-viniferin.
\end{abstract}

Keywords: $\alpha$-viniferin, Dipterocarpaceae, S. ovalis Blume

\section{Introduction}

The human lives are always related to their surround environment including plants. Plants for human being are not only used as sources of food, clothes, or medicine but also used as a source of knowledge. It is predicted that in the world, there are about more than 250,000 of plant species, in which $60 \%$ of them are tropical plants. Of the whole plants, there was only $0.4 \%$ which has been chemically researched, while most of them $(99 \%)$ has never been explored their chemical content (Achmad et al., 1995). Indonesia as the second richest country, after Brazil, in the biological diversity is a leading country in the tropical forest. However this advantage has not been fully investigated, although the presence of the tropical forest as the natural resources of chemical substances is invaluable and potentially to be much more developed (Achmad, 1995)

One of the biological diversities of Indonesian plants is the family of Dipterocarpaceae which is widespread throughout Indonesia. The Dipterocarpaceae is a very large family comprising of 16 genera and about 600 species (Cronquist, 1981; Heyne, 1987). The two biggest genera of Dipterocarpaceae family are Shorea and Dipterocarpus having 150 and 75 species, respectively.

Dipterocarpaceae plant groups, locally known as Meranti, Keruing or Tengkawang, produce variety of compounds such as volatile oil, triterpenoid, flavonoid, arylpropanoid, and oligomeric resveratrol (Heyne, 1987; Sotheeswaran and Pasupathy, 1993). These plants are mainly growth in tropical areas. The chemical research on these plants has long been done (Dai et al., 1998; Ito et al., 2000; Noviany et al., 2002; Saraswathy, et al., 1992; Sultanbawa et al., 1987; Zheng et al., 1994), but for such big family plants, the chemistry of Dipterocarpaceae is relatively less known. This is because the initial research on Dipterocarpaceae was mainly focused on chemical compounds of their resins such as terpenoid, sesquiterpen and triterpen.

Since the finding of hopeaphenol, a polyphenol of oligomeric resveratrol, from two different species of Dipterocarpaceae, i.e Hopea odorata and Balanocarpus heimii, in the last two decades, the phytochemical research on Dipterocarpaceae has shifted rapidly. This is due to the fact that oligomeric resveratrol compounds are the main polyphenol which shows variety of important bioactivities, such as anti inflammation, antibacterial, antifungal, cytotoxicity, chemo preventive, hepatoprotective, and inhibit topoisomerase II, gastric ATPase and 5 $\alpha$-reduktase reactions (Hakim, 2002).

Of the 17 Shorea species which have been researched on, about 11 of them have been mainly researched in Indonesia (Aminah et al., 2001; Aminah et al., 2002; Hakim, 2002; Muharini et al., 2001; Noviany, 2002; Noviany et al., 2002). From the previous researches carried out, the results showed that the phenolic compounds isolated were generally those 
of oligomeric stilbenes. Based on this knowledge, the chemical research on Shorea genera in Indonesia which have not previously been done must be continued as they have high potential as sources of modern medicines. In this research, Shorea ovalis Blume is chosen, as the chemical contents of this species has not been previously reported.

\section{Experiment}

\subsection{General}

Melting points were determined on a Fisher Johns micro-melting point apparatus and are uncorrected. Vacuum liquid chromatography (VLC) was carried out using Merck Si-gel 60, TLC analysis on pre-coated Si-gel plates (Merck Kieselgel $60 \mathrm{~F}_{254}, 0.25 \mathrm{~mm}$ ). The UV lamp of Spectroline, Model ENF-240 C/F was used to see the spot in TLC. UV and IR spectra were measured with Varian Cary 100 Conc. and Shimadzu FT-IR 8501 Scientific spectrophotometers respectively.

\subsection{Plant Material}

Samples of the stem bark of Shorea ovalis Blume were collected in April 2004 from Way Kambas National Park, East Lampung, Indonesia and were identified by the staff at the Herbarium Bogoriense, Research Centre for Biology, Indonesia Institute of Sciences Bogor, Indonesia and a voucher specimen has been deposited at the herbarium.

\subsection{Extraction and Isolation}

The stem bark which has been dried and ground ( $3 \mathrm{~kg}$ ) was macerated with acetone for $3 \times 24$ hours. After the removal of acetone under reduced pressure, the gummy brown residue of acetone extract $(80 \mathrm{~g})$ was obtained. The acetone extract was dissolved in methanol then partitioned with $n$-hexane. Upon evaporation of the solvent, the methanol extract $(50 \mathrm{~g})$ as brown residue was obtained. The methanol extract was then again dissolved in acetone and fractioned twice using VLC ( $200 \mathrm{~g}, 7 \mathrm{~cm} \times 10 \mathrm{~cm}$ ) by increasing polarity ( $n$-hexane, $n$-hexane-ethyl acetate, ethyl acetate, methanol) to give 26 fractions which were grouped into 8 major fractions by combining fractions with similar TLC profiles. The main fraction obtained by combining fraction 22-25 (9 g) was further fractioned with gravity column chromatography and was eluted with mixture of chloroform-ethyl acetate-methanol in increasing polarity. On repeated chromatographic purification, pale yellow crystalline (compound $\mathbf{A}, 8 \mathrm{mg}$ ) mp $231-233{ }^{\circ} \mathrm{C}$ was obtained. The TLC of this compound showed a single spot when it was eluted with three different solvent systems, i.e. $n$-hexane-acetone $(1: 1)$; chloroform : methanol $(85: 15)$ and methanol-dichloromethane $(25: 75)$ with $\mathrm{Rf}$ of $0.3,0.5$, and 0.8 respectively.

\section{Results and Discussion}

The isolated compound (A) was obtained as pale yellow crystalline $(8 \mathrm{mg})$. The UV spectrum of this compound showed $\lambda_{\max .}(\mathrm{MeOH})(\log \varepsilon): 204(1.09), 226(0.66), 285(0.15) \mathrm{nm}$. Upon addition of $\mathrm{NaOH}(\mathrm{MeOH}+\mathrm{NaOH})$ showed $\lambda_{\max }$. ( $\log \varepsilon$ ): 209 (2.47), $250(0.55), 295$ (0.19) nm. The IR spectrum (in KBr) showed vibration bands on 3414, 2920, 1616, $1515,1440,1364,1241,1171,1112,996$, and $831 \mathrm{~cm}^{-1}$.

The UV spectrum (Figure 1) exhibited absorptions $\left(\lambda_{\max } \mathrm{MeOH}\right)(\log \varepsilon) 204$ (1.09), $226(0.66), 285(0.15) \mathrm{nm}$, which indicated a typical of phenolic chromophore (Mattivi et al., 1996). On addition of $\mathrm{NaOH}$ the batochromic shift is not occurred. The IR spectrum (Figure 2) showed absorptions at $3414 \mathrm{~cm}^{-1}, 2920,1616,1515,1440,1364,1241,1171$, $1112,996,831 \mathrm{~cm}^{-1}$ and in the finger print area. The stretch vibration at $3414 \mathrm{~cm}^{-1}$ is the typical of hydroxyl $(\mathrm{OH})$ stretch, and vibration at $2920 \mathrm{~cm}^{-1}$ is characteristic of aliphatic stretch, while absorptions at 1616, 1515, 1440, 1364, and $1241 \mathrm{~cm}^{-1}$ are due to presence of aromatic group of $\mathbf{A}$ (Table 1), and adsorption at $831 \mathrm{~cm}^{-1}$ is indication by the presence of 1,4-disubstituted benzene. The UV and IR showed a typical and characteristic of unconjugated phenolic derivative of oligomeric resveratrol (Mattivi et al., 1996).

The isolated compound $\mathbf{A}$ has similar spectroscopies data to that of compound which has previously been identified from some different genus of Shorea, thus the structure determination of the isolated compound $\mathbf{A}$ was done by comparing to the UV and IR data as shown in Table 1 and 2, respectively and by matching the UV and IR spectra as in Figure 1 and 2, respectively. To strengthen the structure determination of the compound A, the TLC spot of the isolated compound $\mathbf{A}$ was eluted with three different solvent systems i.e. $\quad n$-hexane-acetone (1:1); chloroform : methanol (85: $15)$ and methanol-dichloromethane $(25: 75)$ and the $\mathrm{Rf}$ results were compared with the $\mathrm{Rf}$ of the standard compound, $\alpha$-viniferin, in which the results on the three different solvents showed the same Rf values, i.e. $0.3,0.5$, and 0.8 respectively (Aminah et al., 2001).

Based on the spectroscopies data above and the physical data in Table 3, the values obtained are similar to $\alpha$-viniferin previously reported by Aminah et al. (2001), therefore it was suggested that the compound $\mathbf{A}$ is $\alpha$-viniferin (Table 1, 2 and 3) with the molecule structure as shown in Figure 3. $\alpha$-viniferin, a trimer stilbenoid, is oligomeric stilbene which is always almost present in all Shorea genus. Thus based on chemotaxonomy, S. ovalis Blume also produced oligomeric stilbene compound as expected like other species of Shorea. 
The biological activity of the compound isolated ( $\alpha$-viniferin) has been tested against brine shrimp Artemia salina assay (Meyer et al., 1982) and the lethal concentration 50\% $\left(\mathrm{LC}_{50}\right)$ was found to be $66.9 \mu \mathrm{g} / \mathrm{ml}$. This oligoresveratrol has also been previously reported to have antifungal and anti inflammation activities (Ohyama et al., 1999).

\section{Conclusion}

A trimer stilbene, $\alpha$-viniferin has successfully been isolated from Shorea ovalis Blume. Based on chemotaxonomy, $S$. ovalis Blume has also produced the oligomeric stilbene similar to other species of Shorea. This finding supports the botany taxonomy which shows the close family relation of $S$. ovalis with other Shorea genus and this report also provides new compound obtained in S. ovalis Blume. The chemical research on S. ovalis Blume is still on progress in order to find other oligomeric stilbenes which might present.

\section{Acknowledgements}

The authors would like to thank to The State Ministry for Research and Technology of Republic of Indonesia that provides fund for this project to be undertaken through Basic Science Research Grant Scheme 2004 (PRSD) with contract number of 30/SK/PKRM/II/2004. Thanks also go to Polmer Sinaga, S.Si. and Ardi Fanta Yuda who have helped us in the preparation of the samples. We are also grateful to the Herbarium Bogoriense Bogor, Indonesia, for the assistance in identification of the plant specimen.

\section{References}

Achmad, S.A., Hakim, E.H., Juliawaty, L.D., Kasuma, S., Makmur, L., and Syah, Y.M. (1995). Eksplorasi Kimia Tumbuhan Hutan Tropis Indonesia, Prosiding Seminar Etnobotani dalam Kelompok Penelitian Kimia Bahan Alam, Publikasi dan Presentasi Ilmiah 1993-1995, Bandung. (Indonesian).

Achmad, S.A. (1995). Tiga Periode dalam Revolusi Industri Bahan Kimia Alami, Ceramah Ilmiah, Seminar Nasional Industri Kimia Indonesia dalam Kelompok Penelitian Kimia Bahan Alam, Publikasi dan Presentasi Ilmiah 1993-1995, Bandung. (Indonesian).

Aminah, N.S., Aimi, N., Hakim, E.H., Syah, Y.M., Makmur, L., Juliawaty, L.D., Kitajima, M., Mujahidin, D., Takayama, H. (2001). Oligomer stilbenoids: $\alpha$-viniferin, Hopeaphenol, and Related Compounds from Shorea seminis V.S1. (Dipterocarpaceae), Padang Indonesia, Abstr. P A06. 77.

Aminah, N.S., Achmad, S.A., Aimi, N., Ghisalberti, E.L., Hakim, E.H., Kitajima, M., Syah, Y.M.and Takayama, H. (2002). Diptoindonesin A, a new C-glucoside of E-viniferin from Shorea seminis (Dipterocarpaceae). Fitoterapia, 73 (6), 501-507.

Cronquist, A. (1981). An Integrates System of Classification of Flowering Plants, Columbia Univ. Press., New York. 316-318.

Dai, J.R., Hallock, Y.F., Cardellina, J.H.H., Boyd, M.R. (1998). HIV-Inhibitory and Cytotoxicity Oligostilbenes from the Leaves of Hopea malibato, Journal of Natural Products, 61, 351-353.

Hakim, E.H. (2002). Oligostilbenoid dari Tumbuh-Tumbuhan Dipterocarpaceae, Buletin of the Indonesia Society of Natural Products Chemistry, 2(1), 1-19.

Heyne, K. (1987). Tumbuhan Berguna Indonesia, Vol.II, Balai Kehutanan Indonesia, 1432. (Indonesian).

Ito, T., Tanaka, T., Ido, Y., Nakaya, K., Iinuma, M., Riswan, R. (2000). Stilbenoids Isolated from Stem Bark of Shorea hemsleyana, Chemistry and Pharmacy Bulletin, 48(7), 1001-1005.

Mattivi, F., Reneiro, F., (1996). Relationship between UV spectra and molecular structure of resveratrol oligomers, in Vercauteren, J., Cheze, C. Dumon, M.C., Weber J.F. (Eds). Polyphenols Communication. p.125-126.

Meyer B.N., Mc Laughlin, J.L and Ferrigni, N.R. (1982). Brine Shrimp: a Convenient General Biossay for Active Natural Plant Compounds, Planta Medica, 45, 31-34.

Muharini, R., Hakim, E.H., Achmad, S.A., Aimi, N., Makmur, L., Syah, Y.M., Juliawaty, L.D., Kitajima, M., Mujahidin, D., Takayama, H. (2001). (-)- $\alpha$-viniferin, a Trimer Stilbenoid and Related Compounds from Shorea guiso Blume. Third International Seminar on Tropical Rainforest Plants and Their Utilization for Development, Padang, Indonesia, Abstr., P A12, 83.

Noviany, (2002). Eksplorasi Senyawa Oligomer Stilbenoid dari Tumbuhan Shorea multiflora Burck, Thesis, Bandung Institute of Technology, Indonesia (Indonesian).

Noviany, Hakim, E.H., Achmad, S.A., Aimi, N., Syah, Y.M., Juliawaty, L.D., Ghisalberti E.L., Choudhary I.M. (2002). Beberapa Oligomer Stilbenoid dari Tumbuhan Shorea multiflora Burck. Jurnal Matematika dan Sains, 125-132 (Indonesian). 
Ohyama, M., Tanaka, T., Ito, T., Iinuma, M., Bastow, K.F., Lee, K-H. (1999) Antitumor Agents 200.1 Cytoxicity of Naturally Occuring Resveratrol Oligomers and Their Acetate Derivatives, Bioorganic Medical Chemistry Letters, 9, 3057-3060.

Sotheeswaran, S. and Pasupathy, V. (1993). Distribution of Resveratrol Oligomer in Plants, Phytochemistry, 32, 1083-1092.

Sultanbawa, M.U.S., Surendrakumar, S., Bladon, P. (1987). Distichol, An Antibacterial Polyphenol from Shorea disticha, Phytochemistry, 26(3), 799-801.

Zheng, Z., Zhao, S., Deng, J., Zhao, H., Ye, W., and Wang, M. (1994). Triterpenes from Root Bark of Shorea wangianshuea. Zhongguo Yaoke Daxue Xuebao, 25(5), 262-264.

Table 1. The comparison of UV Spectra data between the compound isolated and standard $\alpha$-viniferin

\begin{tabular}{|c|c|c|c|}
\hline \multicolumn{2}{|c|}{ Isolated Compound } & \multicolumn{2}{c|}{ Standard $\boldsymbol{\alpha}$-viniferin } \\
\hline$\lambda_{\text {max. }}(\mathrm{MeOH})$ & $\lambda_{\text {max. }}(\mathrm{NaOH}+\mathrm{MeOH})$ & $\lambda_{\text {max. }}(\mathrm{MeOH})$ & $\lambda_{\text {max. }}(\mathrm{NaOH}+\mathrm{MeOH})$ \\
\hline $204 \mathrm{~nm}$ & $209 \mathrm{~nm}$ & $206 \mathrm{~nm}$ & $209 \mathrm{~nm}$ \\
\hline $226 \mathrm{~nm}$ & $250 \mathrm{~nm}$ & $266 \mathrm{~nm}$ & $293 \mathrm{~nm}$ \\
\hline $285 \mathrm{~nm}$ & $295 \mathrm{~nm}$ & $342 \mathrm{~nm}$ & $344 \mathrm{~nm}$ \\
\hline
\end{tabular}

Table 2. The comparison of IR spectra data between the isolated compound and standard $\alpha$-viniferin

\begin{tabular}{|c|c|c|c|}
\hline No. & Vibration & Isolated compound $\left.\mathbf{( c m}^{-\mathbf{1}}\right)$ & Standard $\boldsymbol{\alpha}$-viniferin $\left(\mathbf{c m}^{\mathbf{- 1}}\right)$ \\
\hline 1 & OH Strech & 3414 & 3387.2 \\
\hline 2 & - CH aliphatic & 2920 & - \\
\hline 3 & C $=$ C aromatic & $1616,1515,1486,1364,1243$ & $1616,1515,1440,1364,1241$ \\
\hline 4 & 1,4 disubstitution of benzene & 831 & 834 \\
\hline
\end{tabular}

Table 3. The comparison of physical data between the isolated compound and standard $\alpha$-viniferin

\begin{tabular}{|l|c|c|}
\hline \multicolumn{1}{|c|}{ Physical data } & Isolated compound & Standard $\alpha$-viniferin \\
\hline Physical character & Pale yellow crystalline & Pale yellow crystalline \\
\hline Melting point & $231-233^{\circ} \mathrm{C}($ decomposed $)$ & $230^{\circ} \mathrm{C}($ decomposed $)$ \\
\hline$[\alpha]_{\mathrm{D}}{ }^{20}(0.1 \mathrm{M}$ in $\mathrm{MeOH})$ & $-61^{\circ}$ & $-58^{\circ}$ \\
\hline
\end{tabular}




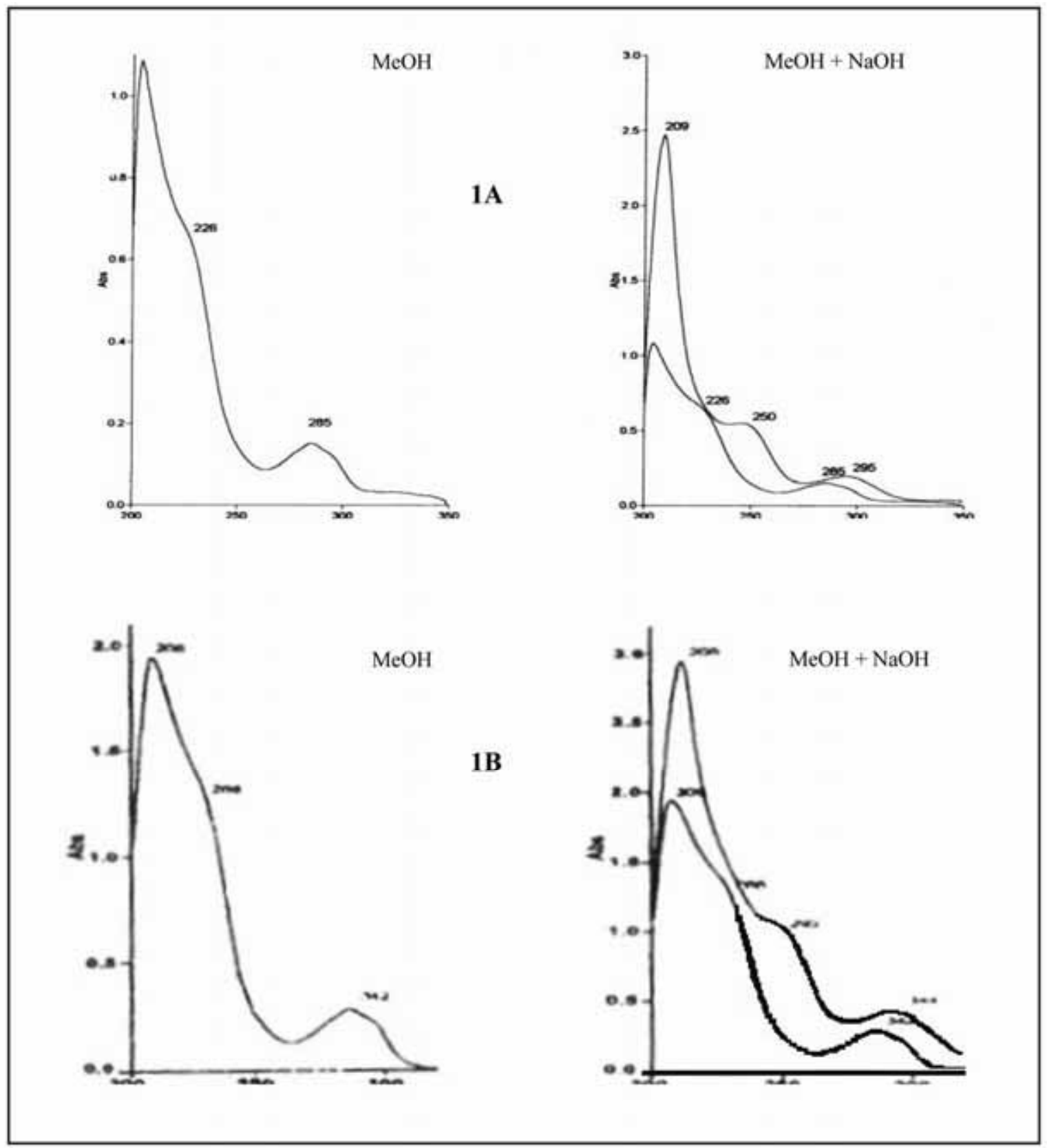

Figure 1. The comparison of UV Spectra between the isolated compound (1A) and standard $\alpha$-viniferin (1B) 


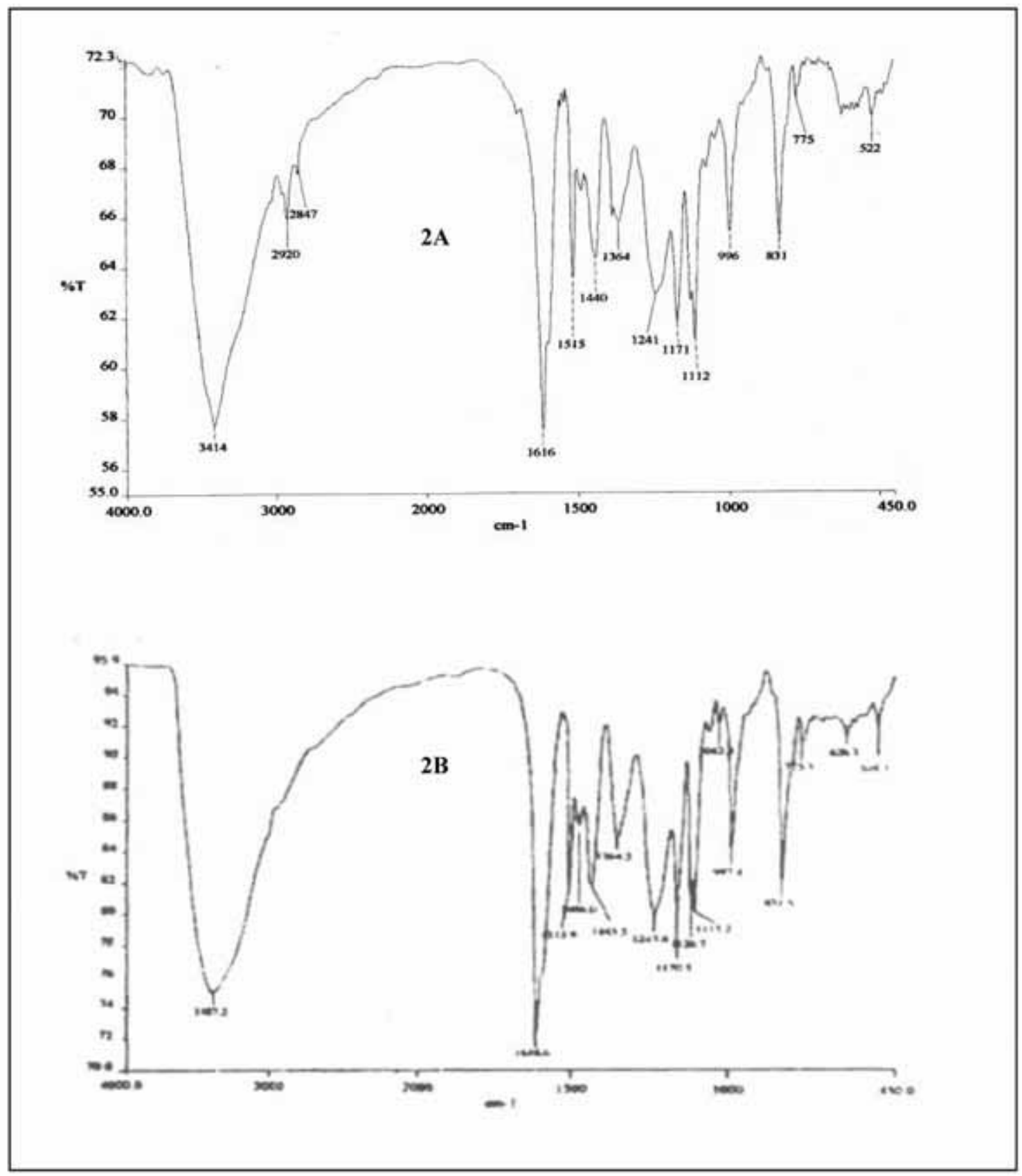

Figure 2. The comparison of IR spectra between the isolated compound (2A) and standard $\alpha$-viniferin (2B) 


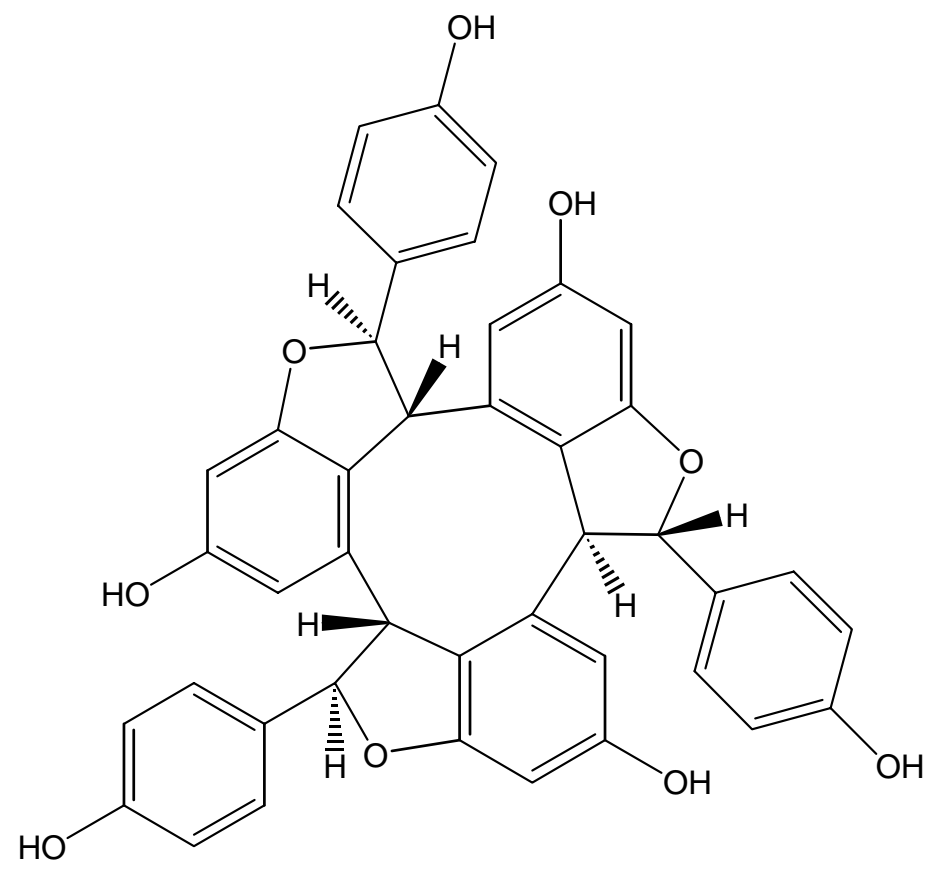

Figure 3. The molecule structure of $\alpha$-viniferin 